\title{
1 Title: Natural Language Processing to Identify Patients with Cognitive Impairment
}

2 Khalil I Hussein, MDa; Lili Chan, MD, MS ${ }^{b}$; Tielman Van Vleck, $\mathrm{PhD}^{\mathrm{c}}$; Kelly Beers, MD ${ }^{\mathrm{b}}$; Monica

3 R Mindt, PhD ; Michael Wolf, PhD, MPH' ; Laura M. Curtis, MS ; Parul Agarwal, PhD ; Juan

4 Wisnivesky, MD ${ }^{\mathrm{a}}$; Girish N. Nadkarni, MD, MPH ${ }^{\mathrm{b}, \mathrm{c}}$; Alex Federman, MD

$5 \quad{ }^{a}$ Division of General Internal Medicine, Department of Medicine, Icahn School of Medicine at

6 Mount Sinai, New York, NY

7 bivision of Nephrology, Department of Medicine, Icahn School of Medicine at Mount Sinai, New

8 York, NY

$9{ }^{\mathrm{c}}$ The Charles Bronfman Institute of Personalized Medicine, Icahn School of Medicine at Mount

10 Sinai, New York, NY

11 dDepartment of Neurology, Icahn School of Medicine at Mount Sinai; Department of Psychology,

12 Fordham University, New York, NY

13 e Institute of Public Health and Medicine, Department of Medicine; Feinberg School of Medicine,

14 Northwestern University, Chicago, Illinois, USA

15 Institute for Health Care Delivery Science, Department of Population Health Science and Policy,

16 Icahn School of Medicine at Mount Sinai

$17{ }^{*} \mathrm{KIH}$ and LC contributed equally and share first authorship, GNN and AF jointly supervised the

18 work

19 Abstract word count: 145

20 Manuscript word count: 3356

21 Tables: 4

22 Figures: 0

23 Running Head: Hussein et al. NLP for CI Identification

24 Corresponding Author:

25 Lili Chan, MD, MS

26 Icahn School of Medicine at Mount Sinai,

27 One Gustave L Levy Place, Box 1243

28 New York, NY-10029

29 Telephone number: (212) 241-8640

30 Fax number: (212) 849-2643

31 Email Address: Lili.Chan@MountSinai.org 


\section{Abstract:}

33 INTRODUCTION: Early detection of patients with cognitive impairment may facilitate care for

34 individuals in this population. Natural language processing (NLP) is a potential approach to

35 identifying patients with cognitive impairment from electronic health records (EHR).

36 METHODS: We used three machine learning algorithms (logistic regression, multilayer

37 perceptron, and random forest) using clinical terms extracted by NLP to predict cognitive

38 impairment in a cohort of 199 patients. Cognitive impairment was defined as a mini-mental

39 status exams (MMSE) score $<24$.

40 RESULTS: NLP identified 69 (35\%) patients with cognitive impairment and ICD codes identified

4144 (22\%). Using MMSE as a reference standard, NLP sensitivity was $35 \%$, specificity $66 \%$,

42 precision $41 \%$, and NPV $61 \%$. The random forest method had the best test parameters;

43 sensitivity $95 \%$, specificity $100 \%$, precision $100 \%$, and NPV $97 \%$

44 DISCUSSION: NLP can identify adults with cognitive impairment with moderate test

45 performance that is enhanced with machine learning.

46 KEYWORDS: Dementia, Cognition, Early Detection, Machine learning, Cognitive Impairment 
medRxiv preprint doi: https://doi.org/10.1101/2022.02.16.22271085; this version posted February 17, 2022. The copyright holder for this preprint (which was not certified by peer review) is the author/funder, who has granted medRxiv a license to display the preprint in perpetuity.

It is made available under a CC-BY-NC-ND 4.0 International license .

\section{Introduction}

Cognitive impairment is common among Americans over the age of 65, with an estimated prevalence as high as $9 \%$ for dementia and $28 \%$ for mild cognitive impairment in some populations. ${ }^{1,2}$ Further, the absolute number of individuals with cognitive difficulties will

52 continue to rise as the U.S. population ages. ${ }^{3}$ Early detection of patients with cognitive

53 impairment may enable primary care providers to facilitate care and care management and

54 improve outcomes for individuals in this population. ${ }^{4}$ Yet systematically identifying patients with

55 cognitive impairment in clinical settings has proven to be logistically difficult. ${ }^{5}$ For example, validated tools for cognitive impairment screening, like the mini Mental State Exam (MMSE) and the Montreal Cognitive Assessment (MoCA), are infrequently used in clinical care, possibly owing to the competing demands of management of multimorbidity in the primary care of older adults. ${ }^{6-11}$ Therefore, a method to efficiently and accurately identify mild cognitive impairment that minimizes primary care provider involvement is necessary.

The rise of healthcare information technology and big data analytics present potential new opportunities to circumvent the existing challenges of identifying patients with cognitive impairment. Electronic health records (EHR) hold an enormous quantum of data beyond traditionally used discrete data elements, like International Classification of Diseases (ICD) diagnosis codes. Free text documentation by clinicians and other members of the health system may hold information about cognitive abilities for the individual, ranging from the nuanced (e.g., "the patient forgets") to the overt (e.g., "family is concerned about dementia"). Such data can be leveraged using advanced informatics approaches for cognitive impairment research. ${ }^{12}$ Natural language processing (NLP) is such an approach. NLP can be used to process large volumes of free text in clinical documentation and convert it into discrete data elements suitable for

71 quantitative analysis. ${ }^{13}$ Machine learning can then be applied to the data elements extracted

72 through NLP to create precise prediction models when a standard measure of cognition is 73 available. In this study, we used NLP and machine learning to identify patients with cognitive 
medRxiv preprint doi: https://doi.org/10.1101/2022.02.16.22271085; this version posted February 17, 2022. The copyright holder for this preprint (which was not certified by peer review) is the author/funder, who has granted medRxiv a license to display the preprint in perpetuity.

It is made available under a CC-BY-NC-ND 4.0 International license .

74

75

76

77

78

\section{7}

impairment using EHR data from an academic medical center and a neurocognitive assessment as the reference standard.

\section{Methods}

\section{Study Population}

Data for this study were obtained from multiple sources. While all patients were part of the BioMe Biobank, patient interview data was obtained from two cohort studies. ${ }^{14}$ The data from these sources were used to characterize study patients and provide a reference standard for cognitive impairment. The cohort studies were conducted in primary care and pulmonary practices in New York City and Chicago, included older adults (ages $\geq 50$ years) with chronic obstructive pulmonary disease (COPD) or asthma, and excluded individuals with dementia based on ICD coding in the electronic record. Patients with diagnosed dementia were excluded since the primary goal of this study was to identify patients with previously undiagnosed cognitive impairment. In both studies, baseline assessments of cognition were conducted by research assistants who were formally trained and supervised in the administration of neuropsychological assessment, including the MMSE, by a research psychologist. ${ }^{15,16}$

The BioMe Biobank is a prospective registry of patients recruited from primary care and subspecialty clinics in the Mount Sinai Health System. Participants consent to the use of their EHR data for biomedical research and the Mount Sinai Institutional Review Board approved the BioME protocols. For the purpose of the present study, we included patients in the cohort studies who had also consented to BioMe participation, and linked their EHR data with cohort study survey data. We retrieved all clinical notes of participants available from the EHR up to December 31, 2017.

\section{Study Design}

Reference Standards for Cognitive Impairment 
medRxiv preprint doi: https://doi.org/10.1101/2022.02.16.22271085; this version posted February 17, 2022. The copyright holder for this preprint (which was not certified by peer review) is the author/funder, who has granted medRxiv a license to display the preprint in perpetuity.

It is made available under a CC-BY-NC-ND 4.0 International license .

The primary reference standard was the mini-Mental State Exam, which was

101

102

103

104

105

106

administered to subjects in both cohort studies at baseline, 12 months, and 24 months.

Research assistants were formally trained and supervised in the administration of neuropsychological assessment by a research psychologist from the Mount Sinai School of Medicine Alzheimer's Disease Research Center. For Spanish-speaking patients, the MMSE was administered in Spanish. We defined cognitive impairment as an unadjusted MMSE score of $<24$ and used data from the most recent assessment. ${ }^{17}$

In a set of secondary analyses, we used physician review of the chart to determine whether there was documented evidence of cognitive impairment. We randomly selected 25 patients who were positive for cognitive impairment by NLP and 25 who were negative. Chart review was independently performed by 2 physicians who were blinded to the results of the NLP analyses and to the ICD codes. Disagreements between the 2 physicians were adjudicated by a third physician. Each reviewer read through all available notes in the EHR. Patients were considered to have cognitive impairment if reviewers found documentation of patient or patient family member complaints of forgetfulness, difficulty learning new things, concentrating, or making decisions to the point of interfering with their everyday life. This could be intermittent or related to a transient condition, such as delirium. Additionally, if a patient was referred to a specialist for dementia workup, reviewers considered this to be positive for cognitive impairment. However, patients forgetting to take medications or to bring in blood pressure/blood sugar logs were not considered to be cognitively impaired, nor were patients who developed altered mental status or cognitive decline while under inpatient hospice care.

\section{Natural Language Processing}

NLP was used to parse all available progress notes and discharge summaries. When using MMSE as a reference only notes from a 24-month period, between 12 months prior to and 12 months after the most recent MMSE administration was used. Since the MMSE was 
medRxiv preprint doi: https://doi.org/10.1101/2022.02.16.22271085; this version posted February 17, 2022. The copyright holder for this preprint (which was not certified by peer review) is the author/funder, who has granted medRxiv a license to display the preprint in perpetuity.

It is made available under a CC-BY-NC-ND 4.0 International license .

obtained at a defined time, this time restriction allows for inclusion of only notes that reflect the provider assessment of the patients' cognitive function around the time of the MMSE. This avoids including notes from patients who may have developed cognitive impairment after the MMSE. However, when we compared the NLP algorithm to manual chart review and ICD codes, since the entire chart was reviewed, there were no time restrictions to the notes for NLP querying. We excluded radiology reports and pathology reports as text from these note types are generally devoid of assessments of cognition. The NLP program matched words and phrases in EHR free-text documentation to clinical terms of the Systematized Nomenclature of Medicine - Clinical Terms (SNOMED CT). SNOMED is a comprehensive healthcare terminology consisting of hierarchies of concepts, with parent terms encompassing specific concepts (child terms). ${ }^{18}$ Two physicians independently reviewed available SNOMED CT for terms associated with cognitive impairment to be used for NLP querying. The SNOMED CT parent and child terms included in the query are diagrammed in eFigure 1.

\section{For each of these terms a query was created to identify instances of the concept} documented as present in the clinical record and determined whether it represented the subject of record (the patient vs. a family member) and its temporality (current or past). We defined cognitive impairment by NLP as identification of $\geq 1$ term in the medical record linked to cognitive impairment by SNOMED CT. Cognitive impairment was not considered present when negation terms, e.g., not or no, were used in the same sentence or when cognitive impairment was mentioned in the context of family history. NLP was performed using CLiX NLP (Clinithink, London, UK).

After first use of NLP to identify patients with cognitive impairment, we conducted a manual review of 50 randomly selected charts to identify and correct inaccuracies in the NLP strategy that could lead to false positive and negative results. For example, NLP labeled one patient as having cognitive impairment when it recognized the "mCi" abbreviation used for "millicurie" (a unit of radioactivity) as indicative of mild cognitive impairment. 
medRxiv preprint doi: https://doi.org/10.1101/2022.02.16.22271085; this version posted February 17, 2022. The copyright holder for this preprint (which was not certified by peer review) is the author/funder, who has granted medRxiv a license to display the preprint in perpetuity.

It is made available under a CC-BY-NC-ND 4.0 International license .

We also used ICD 9 and 10 codes to identify patients with cognitive impairment (eTable

1). ${ }^{19,20}$ The codes we used included $290 . x$ (dementias, including senile and vascular), 294.x

156 (persistent mental disorders due to conditions classified elsewhere, e.g., amnestic disorder in

157 conditions classified elsewhere, dementia unspecified), F01.x (vascular dementia), and F01.x

158 (unspecified dementia).

Machine Learning Strategy

In order to develop a machine learning approach to predicting cognitive impairment from free text data, all SNOMED terms were extracted from every available progress note for all patients for the 24 month period of observation. Each data element matched to a SNOMED clinical term has 4 features (temporality, association, subject relationship, finding or presence of the condition). An example is presented in eFigure 2 for the term "forgetful". While an asset when trying to describe patient features in great detail, the granularity of textual data parsed by NLP complicates the correlation of patients with similar traits when sample sizes (number of patients) are small. To resolve this complexity, we eliminated parts of the SNOMED expression that were unnecessary for analysis such as redundant modifiers. As the SNOMED expressions alone do not capture the logical hierarchy of SNOMED, we also walked up the SNOMED

171 hierarchy and created additional features for relevant children concepts. Thus, for the parent

172 term "cognitive impairment," the additional features were created to represent the children

173 concepts of forgetful, memory impairment, memory finding, cognitive function finding, mental

174 state, behavior and/or psychosocial function finding, and impaired cognition. We then trained 175 and tested machine learning classifiers using only the condensed output from our NLP algorithm

176 to predict whether the patient would have MMSE score $<24$. Classification methods included 177 logistic regression, multilayer perceptron (MLP) a feedforward neural network ${ }^{21}$, and random 
forest. ${ }^{22}$ We performed 100 -fold cross validation. Models were trained on a varying number of top features, according to K-Means correlation with MMSE <24. All machine learning procedures were performed in Python, using the standard scikit-learn package.

\section{Statistical Analysis}

We assessed performance of NLP, ICD, and the combination of NLP and/or ICD codes for identification of patients with cognitive impairment by calculating the sensitivity, specificity, precision (also knowns as positive predictive value), negative predictive value (NPV), and F1 scores, using MMSE scores and determination by manual chart review as the primary and secondary reference standards, respectively. We performed comparison of categorical demographic variables by cognitive impairment status using Chi Square and Fisher Exact tests and t-tests for continuous variables. We calculated kappa statistic for inter-rater agreement for manual chart review using SAS Macro MAGREE. All statistics were calculated using SAS version 9.4 (SAS Institute, Cary, NC).

\section{Results}

\section{Subject Characteristics}

We linked EHR and cognitive assessment data for 199 patients. The average age of patients was $68 \pm 7$. They were predominantly female $(75 \%)$, Hispanic $(53 \%)$, and low income ( $<\$ 750$ per month, $51 \%$ ); $46 \%$ had completed less than 12 years of formal education (Table 1 ). MMSE score was less than 24 for 79 (40\%) patients and was more common with increasing age, lower education, poorer general health, and Spanish language preference.

\section{Performance of NLP and ICD Codes with MMSE Assessment as the Reference Standard}

NLP identified 69 (35\%) patients as having cognitive impairment and ICD codes identified $44(22 \%)$. Sensitivity of NLP for detection of cognitive impairment was low, 0.35 (95\% 
CI 0.25-0.47), while specificity was moderate, 0.66 (95\% CI 0.57-0.74) (Table 2). Use of ICD 9

205

206

207

208

209

210

211

212

213

214

215

216

217

218

219

220

221

222

223

224

225

226

227

228

229

and 10 codes to detect cognitive impairment performed similarly (sensitivity, 0.24 (95\% Cl 0.130.59); specificity, $0.79(95 \% \mathrm{Cl} 0.6-0.91)$. Negative and positive predictive and F1 values were also similar for the two strategies (Table 2). Combining NLP and ICD codes into a single diagnostic strategy did not meaningfully alter test performance compared to either approach alone: sensitivity, 0.41 (95\% Cl 0.3-0.52); specificity, 0.63 (95\% Cl 0.54-0.72).

\section{Performance of NLP and ICD Codes with Manual Chart Review as the Reference Standard} Agreement between reviewers for chart review was high (kappa $0.78,95 \% \mathrm{Cl} 0.62-$ 0.94). Sensitivity of NLP for cognitive impairment as determined by manual chart review was high, 0.96 (95\% Cl 0.75-1), specificity was moderate, 0.68 (95\% Cl 0.5-0.82), and precision was moderate $0.52(95 \% \mathrm{CI} 0.31-0.72)$ (Table 3). ICD 9 and 10 codes for cognitive impairment by manual chart review had moderate sensitivity, 0.77 (95\% Cl 0.46-0.95), high specificity, 0.92 (95\% Cl 0.78-0.98), and moderate precision 0.77 (95\% Cl 0.46-0.95). NPV and F1 scores were similar for the two strategies (Table 3). The combination of NLP and ICD codes as a single diagnostic strategy did not substantially change test performance: sensitivity 0.96 (95\% Cl 0.75 1), specificity 0.7 (95\% Cl 0.5-0.82), precision 0.52 (95\% Cl 0.31-0.72), NPV 0.98 (95\% Cl 0.861), and F1 score of 0.68 .

\section{Machine Learning with NLP terms for Identification of Cognitive Impairment}

Application of machine learning to NLP-identified terms resulted in substantial improvements in identification of patients with cognitive impairment with respect to the MMSE reference standard (Table 4). Of the three classifiers tested, the Random Forest method performed best, though only slightly better than the MLP neural net. The Random Forest approach yielded a sensitivity of 0.95 , specificity 1.00 , precision 1.00 , NPV 0.97, F1 score of 0.98 with overall AUC 0.98. For Supervised Neural Network (MLP Classifier) approach, 
medRxiv preprint doi: https://doi.org/10.1101/2022.02.16.22271085; this version posted February 17, 2022. The copyright holder for this preprint (which was not certified by peer review) is the author/funder, who has granted medRxiv a license to display the preprint in perpetuity.

It is made available under a CC-BY-NC-ND 4.0 International license .

sensitivity was 0.94 , specificity 1.00 , precision 1.00 , NPV $0.96, F 1$ score of 0.97 with overall AUC 0.97. Lastly, for the logistic regression approach sensitivity was 0.63 , specificity 0.98 , precision 0.95 , NPV 0.79 , F1 score of 0.76 with overall AUC 0.80 .

\section{Discussion}

In this study, we used NLP to identify patients with cognitive impairment from EHR documentation and found that it had modest test performance in relation to the MMSE, a standardized assessment. NLP performed similarly to ICD codes when using MMSE as the reference standard but had better performance when using manual review as the reference standard. However, applying machine learning approaches to the concepts extracted by NLP greatly improved test performance.

Our study builds on prior literature aimed at detection of patients with cognitive impairment. Multiple studies have utilized NLP to analyze patient speech patterns to identify cognitive impairment. ${ }^{23-25}$ However, this approach requires prospective collection of recordings or transcription of patient-physician visits and may be logistically challenging in clinical practice. Only one study has used NLP with EHR data. ${ }^{20}$ Reuben et al used medications, ICD codes, and NLP to identify patients with dementia and compared it to physician manual chart review. Their NLP algorithm only included terms for "dementia" or "neurodegenerative" without negation terms or family history markers. We used a more complex NLP algorithm that was based on SNOMED terms and hierarchy, therefore including a more extensive list of terms for querying. This may have contributed to the higher sensitivity we found compared to that reported by Reuben et al. Additionally, our main comparison was between NLP and an objective cognitive assessment with the MMSE, rather than chart review.

As the proportion of older adults in the US population increases, the number of patients with cognitive impairment is also increasing. Cognitive impairment puts a strain on the US healthcare system as it is a major risk factor for hospital admission and readmissions, and a 
medRxiv preprint doi: https://doi.org/10.1101/2022.02.16.22271085; this version posted February 17, 2022. The copyright holder for this preprint (which was not certified by peer review) is the author/funder, who has granted medRxiv a license to display the preprint in perpetuity.

It is made available under a CC-BY-NC-ND 4.0 International license .

256

257

258

259

260

major contributor of healthcare costs among older adults. ${ }^{26-29}$ Additionally, cognitive impairment negatively impacts an individual's life by affecting their ability to self-manage chronic diseases, as a risk factor for functional status decline, and contributes to the development of depression and other chronic health problems..$^{30-33}$ Despite this, cognitive impairment is under-recognized with only $8-28 \%$ of older adults every being screened and on average 10 years between the appearance of early declines in cognitive function and a clinician diagnosis.

While our NLP and machine learning approach requires additional validation, since it is based on existing EHR, it can be easily implemented into EHR systems. One proposed method would be a clinical decision support system, which can notify patient's providers when the algorithm identifies a patient with cognitive impairment and suggest potential actions to take such as referrals to neuropsychological testing or assessment for the need of a home health aide. This EHR-based intervention could most benefit patients who regularly interact with healthcare providers that typically do not screen existing clinical data in the chart for evidence of cognitive impairment. For example, an elderly patient who is frequently admitted to a hospital and regularly follows up with multiple specialists for non-cognitive concerns but rarely sees a primary care physician, geriatrician, psychiatrist, or neurologist could easily avoid formal cognitive screening despite risk factors. Because our proposed cognitive impairment detection tools would only use data already contained within the EHR, would only be visible to the patient's providers, and would only suggest the initiation of the cognitive impairment diagnostic workup rather than attempt to establish the diagnosis itself, this intervention would not raise privacy or other ethical concerns.

Early detection of cognitive impairment is advocated by the US Department of Health and Human Services and the Alzheimer's Foundation. ${ }^{34,35}$ Early identification can allow for enrollment into programs to exclude reversible causes of dementia, cognitive intervention programs $^{36}$, pharmacotherapy when appropriate, and identifying care coordination needs. ${ }^{37}$ Additionally, identification will enable care givers to receive support to alleviate the stress and 
medRxiv preprint doi: https://doi.org/10.1101/2022.02.16.22271085; this version posted February 17, 2022. The copyright holder for this preprint (which was not certified by peer review) is the author/funder, who has granted medRxiv a license to display the preprint in perpetuity.

It is made available under a CC-BY-NC-ND 4.0 International license .

282

283

284

285

286

287

288

289

290

291

292

293

294

295

296

297

298

299

300

301

302

303

304

305

306

burden associated with caring for people with cognitive impairment. Lastly, effective and efficient methods of identifying patients with cognitive impairment will allow for inclusion of these patients into clinical trials and cohort studies. Our NLP and machine learning approach is a scalable method that can facilitate identification given its high sensitivity, understanding that there is the potential for false positive given the lower specificity. As with any screening test, there can be false negatives and false positives. A false negative will lead to a delay in a patient with cognitive impairment receiving appropriate referrals for care, while a false positive will lead to unnecessary additional testing and can cause patient's unneeded stress. Therefore, validation of our results are necessary before implementation.

In this study, patients who had lower MMSE scores were older, had less education, and preferred to communicate in Spanish. It has been well established that age, education, and language are associated with lower MMSE scores. ${ }^{38}$ Some researchers have performed age and education adjustment, which increases the sensitivity but decreases the specificity of the MMSE. ${ }^{39}$ Lastly, others have argued against using adjustment for education as there may be a true association between education level and cognitive impairment. ${ }^{40}$ Due to this uncertainty and that our study is a proof of concept that NLP can be used to identify patients with cognitive impairment, we chose to use the unadjusted cutoff of 24 consistent with mild impairment that is a widely accepted threshold for cognitive impairment in our analyses.

We chose to not include medications in the NLP or machine learning algorithm. Prior studies did not find that the addition of medications improved performance of their NLP or ICD algorithms for dementia identification. ${ }^{20}$ Authors cite the use of dementia medications for alternative diagnoses as a possible cause. We found a higher prevalence of cognitive impairment than the $15-25 \%$ that is reported in literature, which may be due to the inclusion of only older adults with asthma or COPD, two conditions having established associations with cognitive impairment in older adults. ${ }^{41}$ Differences between sensitivity of NLP when using 
medRxiv preprint doi: https://doi.org/10.1101/2022.02.16.22271085; this version posted February 17, 2022. The copyright holder for this preprint (which was not certified by peer review) is the author/funder, who has granted medRxiv a license to display the preprint in perpetuity.

It is made available under a CC-BY-NC-ND 4.0 International license .

MMSE as a standard and chart review as a standard may be influenced by the under diagnosis of cognitive impairment by providers and therefore not documented in the chart. ${ }^{42}$

This study has several limitations. First, the sample size was relatively small, which could have led to overfitting of the machine learning algorithm. We performed a 100 -fold cross validation to reduce the risk of overfitting, but validation with data from a different health system is needed before conclusions can be drawn about the NLP and machine learning strategies we employed. As NLP can only identify cognitive impairment from what is in the EHR, it is dependent on the number of encounters and notes available. While there are many methods of identifying cognitive impairment, we only used the MMSE, which can be biased by a person's education, primary language, and culture. Despite these limitations, this is the first study to use NLP and machine learning to identify patients with cognitive impairment using data from EHR.

\section{Conclusion}

NLP can be used to identify adults with cognitive impairment with moderate test performance and greatly enhanced with the addition of machine learning. NLP and machine learning out performed ICD codes for identification of cognitive impairment. While additional validation in external datasets is necessary, this method provides for a scalable and high throughput method for identifying patients with cognitive impairment for more appropriate diagnostic testing, early treatment, and enrollment into research studies.

Acknowledgements: Data, analytic methods, and study materials can be made available after review and approval by institutional regulatory bodies. The study was not preregistered in any public registry.

Conflict of Interest: TVV was part of launching Clinithink and retains a financial interest in the company.

\section{Funding: This research was funded by a grant from the National Institute on Aging,} R01AG066471. 
334 Author Contributions: KIH, LC, TVV, KB, PA, JW, GNN, and AF were responsible for the 335 conception, design, and acquisition, design, and interpretation of the data. $\mathrm{KIH}, \mathrm{LC}, \mathrm{GNN}, \mathrm{AF}$, 336 MRM, MW, LMC assisted in the drafting and critical revision of the manuscript. All authors 337 approve of the final version of the manuscript. 


\section{References}

340 1. Ward A, Arrighi HM, Michels S, Cedarbaum JM. Mild cognitive impairment: Disparity of incidence and prevalence estimates. Alzheimer's Dement. 2012.

2. Langa KM, Larson EB, Crimmins EM, et al. A comparison of the prevalence of dementia in the United States in 2000 and 2012. JAMA Intern Med. 2017. doi:10.1001/jamainternmed.2016.6807

3. Matthews KA, Xu W, Gaglioti AH, et al. Racial and ethnic estimates of Alzheimer's disease and related dementias in the United States (2015-2060) in adults aged $\geq 65$ years. Alzheimer's Dement. 2019. doi:10.1016/j.jalz.2018.06.3063

4. Borson S, Frank L, Bayley PJ, et al. Improving dementia care: The role of screening and detection of cognitive impairment. Alzheimer's Dement. 2013. doi:10.1016/j.jalz.2012.08.008

5. Wilkinson $\mathrm{T}$, Ly A, Schnier $\mathrm{C}$, et al. Identifying dementia cases with routinely collected health data: A systematic review. Alzheimers Dement. 2018;14(8):1038-1051. doi:10.1016/j.jalz.2018.02.016

6. Scott J, Mayo AM. Instruments for detection and screening of cognitive impairment for older adults in primary care settings: A review. Geriatr Nurs (Minneap). 2018. doi:10.1016/j.gerinurse.2017.11.001

7. Kotagal V, Langa KM, Plassman BL, et al. Factors associated with cognitive evaluations in the United States. Neurology. 2015. doi:10.1212/WNL.0000000000001096

8. Moga DC, Roberts M, Jicha G. Dementia for the Primary Care Provider. Prim Care - Clin

9. Boustani M. Dementia Screening in Primary Care: Not Too Fast! J Am Geriatr Soc. 2013. doi:10.1111/jgs.12319_2

10. Linzer M, Poplau S, Babbott S, et al. Worklife and Wellness in Academic General Internal Medicine: Results from a National Survey. J Gen Intern Med. 2016. doi:10.1007/s11606016-3720-4

11. Rabatin J, Williams E, Baier Manwell L, Schwartz MD, Brown RL, Linzer M. Predictors and Outcomes of Burnout in Primary Care Physicians. J Prim Care Community Health. 2016. doi: $10.1177 / 2150131915607799$

12. Zhang R, Simon G, Yu F. Advancing Alzheimer's research: A review of big data promises. Int J Med Inform. 2017. doi:10.1016/j.jmedinf.2017.07.002

13. Nadkarni PM, Ohno-Machado L, Chapman WW. Natural language processing: An introduction. J Am Med Informatics Assoc. 2011. doi:10.1136/amiajnl-2011-000464

14. Levin MA, Joseph TT, Jeff JM, et al. iGAS: A framework for using electronic intraoperative medical records for genomic discovery. J Biomed Inform. 2017. doi:10.1016/j.jbi.2017.02.005

15. Krauskopf K, Federman AD, Kale MS, et al. Chronic obstructive pulmonary disease illness and medication beliefs are associated with medication adherence. COPD J Chronic Obstr Pulm Dis. 2015. doi:10.3109/15412555.2014.922067 
medRxiv preprint doi: https://doi.org/10.1101/2022.02.16.22271085; this version posted February 17, 2022. The copyright holder for this preprint (which was not certified by peer review) is the author/funder, who has granted medRxiv a license to display the preprint in perpetuity. It is made available under a CC-BY-NC-ND 4.0 International license .

16. Ray M, Sano M, Wisnivesky JP, Wolf MS, Federman AD. Asthma control and cognitive function in a cohort of elderly adults. J Am Geriatr Soc. 2015. doi:10.1111/jgs.13350

17. Folstein MF, Folstein SE, McHugh PR. "Mini-mental state": A practical method for grading the cognitive state of patients for the clinician. J Psychiatr Res. 1975;12(3):189-198. doi:10.1016/0022-3956(75)90026-6

18. Spackman KA, Campbell KE, Côté RA. SNOMED RT: a reference terminology for health care. Proc a Conf Am Med Informatics Assoc AMIA Fall Symp. 1997:640-644. http://www.ncbi.nlm.nih.gov/pubmed/9357704. Accessed July 25, 2017.

19. St. Germaine-Smith C, Metcalfe A, Pringsheim T, et al. Recommendations for optimal ICD codes to study neurologic conditions a systematic review. Neurology. 2012. doi:10.1212/WNL.0b013e3182684707

20. Reuben DB, Hackbarth AS, Wenger NS, Tan ZS, Jennings LA. An Automated Approach to Identifying Patients with Dementia Using Electronic Medical Records. J Am Geriatr Soc. 2017. doi:10.1111/jgs. 14744

21. Pal SK, Mitra S. Multilayer perceptron, fuzzy sets, and classification. IEEE Trans Neural Networks. 1992;3(5):683-697. doi:10.1109/72.159058

22. Breiman L. Random Forrests. Mach Learn. 2001.

23. Mirheidari B, Blackburn D, Harkness K, et al. An avatar-based system for identifying individuals likely to develop dementia. In: Proceedings of the Annual Conference of the International Speech Communication Association, INTERSPEECH. ; 2017. doi:10.21437/Interspeech.2017-690

24. Thomas C, Kešelj V, Cercone N, Rockwood K, Asp E. Automatic detection and rating of dementia of alzheimer type through lexical analysis of spontaneous speech. In: IEEE International Conference on Mechatronics and Automation, ICMA 2005. ; 2005.

25. Orimaye SO, Wong JS-M, Golden KJ, Wong CP, Soyiri IN. Predicting probable Alzheimer's disease using linguistic deficits and biomarkers. BMC Bioinformatics. 2017;18(1):34. doi:10.1186/s12859-016-1456-0

26. Greenwald JL, Cronin PR, Carballo V, Danaei G, Choy G. A Novel Model for Predicting Rehospitalization Risk Incorporating Physical Function, Cognitive Status, and Psychosocial Support Using Natural Language Processing. Med Care. 2017. doi:10.1097/MLR.0000000000000651

27. Callahan KE, Lovato JF, Miller ME, Easterling D, Snitz B, Williamson JD. Associations between mild cognitive impairment and hospitalization and readmission. J Am Geriatr Soc. 2015. doi:10.1111/jgs.13593

28. Lin PJ, Zhong Y, Fillit HM, Chen E, Neumann PJ. Medicare Expenditures of Individuals with Alzheimer's Disease and Related Dementias or Mild Cognitive Impairment Before and After Diagnosis. J Am Geriatr Soc. 2016. doi:10.1111/jgs.14227

29. Lin PJ, Neumann PJ. The economics of mild cognitive impairment. Alzheimer's Dement. 2013. doi:10.1016/j.jalz.2012.05.2117

30. Soones TN, Lin JL, Wolf MS, et al. Pathways linking health literacy, health beliefs, and cognition to medication adherence in older adults with asthma. J Allergy Clin Immunol. 2017. doi:10.1016/j.jaci.2016.05.043 
medRxiv preprint doi: https://doi.org/10.1101/2022.02.16.22271085; this version posted February 17, 2022. The copyright holder for this preprint

(which was not certified by peer review) is the author/funder, who has granted medRxiv a license to display the preprint in perpetuity.

It is made available under a CC-BY-NC-ND 4.0 International license .

422

423

424

425

426

427

428

429

430

431

432

433

434

435

436

437

438

439

440

441

442

443

444

445

446

447

448

449

450

451

452

453

454

455

456

457

458

459

460

461

462

463

464

31. Stuck AE, Walthert JM, Nikolaus T, Büla CJ, Hohmann C, Beck JC. Risk factors for functional status decline in community-living elderly people: A systematic literature review. Soc Sci Med. 1999. doi:10.1016/S0277-9536(98)00370-0

32. Dotson VM, Resnick SM, Zonderman AB. Differential association of concurrent, baseline, and average depressive symptoms with cognitive decline in older adults. Am J Geriatr Psychiatry. 2008. doi:10.1097/JGP.0b013e3181662a9c

33. Sanders JB, Bremmer MA, Comijs HC, Deeg DJH, Lampe IK, Beekman ATF. Cognitive functioning and the natural course of depressive symptoms in late life. Am J Geriatr Psychiatry. 2011. doi:10.1097/JGP.0b013e3181f7d8e9

34. 2019 ALZHEIMER'S DISEASE FACTS AND FIGURES Includes a Special Report on Alzheimer's Detection in the Primary Care Setting: Connecting Patients and Physicians. https://www.alz.org/media/Documents/alzheimers-facts-and-figures-2019-r.pdf. Accessed July 15, 2019.

35. National Plan to Address Alzheimer's Disease: 2018 Update. https://aspe.hhs.gov/system/files/pdf/259581/NatPlan2018.pdf. Accessed July 15, 2019.

36. Hong Y, Jang E, Hwang J, Roh J, Lee J-H. The Efficacy of Cognitive Intervention Programs for Mild Cognitive Impairment: A Systematic Review. Curr Alzheimer Res. 2015. doi:10.2174/1567205012666150530201636

37. Backhouse A, Ukoumunne OC, Richards DA, McCabe R, Watkins R, Dickens C. The effectiveness of community-based coordinating interventions in dementia care: A metaanalysis and subgroup analysis of intervention components. BMC Health Serv Res. 2017. doi:10.1186/s12913-017-2677-2

38. Crum RM. Population-Based Norms for the Mini-Mental State Examination by Age and Educational Level. JAMA J Am Med Assoc. 1993;269(18):2386. doi:10.1001/jama.1993.03500180078038

39. Mungas D, Marshall SC, Weldon M, Haan M, Reed BR. Age and education correction of mini-mental state examination for english- and spanish-speaking elderly. Neurology. 1996. doi:10.1212/WNL.46.3.700

40. Pedraza O, Clark JH, O'Bryant SE, et al. Diagnostic validity of age and education corrections for the mini-mental state examination in older African Americans. J Am Geriatr Soc. 2012. doi:10.1111/j.1532-5415.2011.03766.x

41. Creavin ST, Wisniewski S, Noel-Storr AH, et al. Mini-Mental State Examination (MMSE) for the detection of dementia in clinically unevaluated people aged 65 and over in community and primary care populations. Cochrane Database Syst Rev. 2016;(1). doi:10.1002/14651858.CD011145.pub2

42. Berkman LF. The association between educational attainment and mental status examinations: Of etiologic significance for senile dementias or not? J Chronic Dis. 1986. doi:10.1016/0021-9681(86)90020-2

43. Roberts R, Knopman DS. Classification and epidemiology of MCl. Clin Geriatr Med. 2013. doi:10.1016/j.cger.2013.07.003

44. Bradford A, Kunik ME, Schulz P, Williams SP, Singh H. Missed and delayed diagnosis of dementia in primary care: Prevalence and contributing factors. Alzheimer Dis Assoc Disord. 2009. doi:10.1097/WAD.0b013e3181a6bebc 
medRxiv preprint doi: https://doi.org/10.1101/2022.02.16.22271085; this version posted February 17, 2022. The copyright holder for this preprint

(which was not certified by peer review) is the author/funder, who has granted medRxiv a license to display the preprint in perpetuity.

It is made available under a CC-BY-NC-ND 4.0 International license.

465

466 
medRxiv preprint doi: https://doi.org/10.1101/2022.02.16.22271085; this version posted February 17, 2022. The copyright holder for this preprint (which was not certified by peer review) is the author/funder, who has granted medRxiv a license to display the preprint in perpetuity.

Table 1: Demographics

\begin{tabular}{|c|c|c|c|c|c|}
\hline \multirow{2}{*}{\multicolumn{2}{|c|}{ Characteristic }} & $\begin{array}{c}\text { Total } \\
(\mathrm{n}=199)\end{array}$ & $\begin{array}{c}\text { MMSE }<24 \\
(n=79)\end{array}$ & $\begin{array}{l}\mathrm{MMSE}_{\geq 224} \\
(\mathrm{n}=120)\end{array}$ & p-value \\
\hline & & $\mathrm{n}(\%)$ & $\mathrm{n}(\%)$ & $\mathrm{n}(\%)$ & \\
\hline \multicolumn{6}{|l|}{ Age } \\
\hline & $55-64$ & $88(44.2 \%)$ & $25(31.7 \%)$ & $63(52.5 \%)$ & 0.008 \\
\hline & $65-70$ & $58(29.2 \%)$ & $31(39.2 \%)$ & $27(22.5 \%)$ & \\
\hline & $\geq 71$ & $53(26.6 \%)$ & $23(29.1 \%)$ & $30(25.0 \%)$ & \\
\hline \multicolumn{2}{|c|}{ Female } & $149(74.9 \%)$ & $56(70.9 \%)$ & $93(77.5 \%)$ & 0.29 \\
\hline \multicolumn{2}{|c|}{ Married/Living with Partner } & $44(22.1 \%)$ & $17(21.5 \%)$ & $27(22.5 \%)$ & 0.87 \\
\hline \multicolumn{6}{|c|}{ Race } \\
\hline & White & $29(14.6 \%)$ & 7 (8.9\%) & $22(18.3 \%)$ & 0.27 \\
\hline & Black & $56(28.1 \%)$ & $22(27.8 \%)$ & $34(28.3 \%)$ & \\
\hline & Hispanic & $106(53.3 \%)$ & $47(59.5 \%)$ & $59(49.2 \%)$ & \\
\hline & Other & $8(4.0 \%)$ & $3(3.8 \%)$ & $5(4.2 \%)$ & \\
\hline \multicolumn{6}{|c|}{ Monthly Income } \\
\hline & $\$ 0-\$ 750$ & $100(50.8 \%)$ & $38(48.1 \%)$ & $62(51.7 \%)$ & 0.63 \\
\hline & $\$ 751-\$ 1350$ & $62(31.5 \%)$ & $28(35.4 \%)$ & $34(28.3 \%)$ & \\
\hline & $\$ 1351-\$ 3000$ & $23(11.6 \%)$ & $8(10.1 \%)$ & $15(12.5 \%)$ & \\
\hline & $>\$ 3000$ & $6(3.1 \%)$ & $1(1.3 \%)$ & $5(4.2 \%)$ & \\
\hline & Refused/Don't Know & $8(4.0 \%)$ & $4(5.1 \%)$ & $4(3.3 \%)$ & \\
\hline \multicolumn{6}{|c|}{ Education } \\
\hline & Less than 12 years & $91(45.7 \%)$ & $50(63.3 \%)$ & $41(34.2 \%)$ & $<0.001$ \\
\hline & High school graduate & $42(21.1 \%)$ & $12(15.2 \%)$ & $30(25.0 \%)$ & \\
\hline & Some college & $35(17.6 \%)$ & $9(11.4 \%)$ & $26(21.7 \%)$ & \\
\hline & $\begin{array}{l}\text { College degree or } \\
\text { higher }\end{array}$ & $30(15.1 \%)$ & $7(8.9 \%)$ & $23(19.2 \%)$ & \\
\hline & Refused/Don't Know & $1(0.5 \%)$ & $1(1.3 \%)$ & $0(0.0 \%)$ & \\
\hline \multicolumn{6}{|c|}{ General Health Rating } \\
\hline & Excellent/Very Good & $29(14.6 \%)$ & $6(7.6 \%)$ & $23(19.2 \%)$ & 0.003 \\
\hline & Good & $53(26.6 \%)$ & $15(19.0 \%)$ & $38(31.7 \%)$ & \\
\hline & Fair/Poor & $117(58.8 \%)$ & $58(73.4 \%)$ & $59(49.2 \%)$ & \\
\hline \multicolumn{6}{|c|}{ Assistance with ADLs } \\
\hline & No help & $123(61.8 \%)$ & $42(53.1 \%)$ & $81(67.5 \%)$ & 0.08 \\
\hline & Help needed & $74(37.2 \%)$ & $36(45.6 \%)$ & $38(31.7 \%)$ & \\
\hline & Refused/Don't Know & $2(1.0 \%)$ & $1(1.3 \%)$ & $1(0.8 \%)$ & \\
\hline \multicolumn{6}{|c|}{ Origin Country/Territory } \\
\hline & United States & $103(51.8 \%)$ & $33(41.8 \%)$ & $70(58.3 \%)$ & 0.02 \\
\hline & Puerto Rico & $73(36.7 \%)$ & $34(43.0 \%)$ & $39(32.5 \%)$ & \\
\hline & Dominican Republic & $9(4.5 \%)$ & $7(8.9 \%)$ & $2(1.7 \%)$ & \\
\hline & Other & $14(7.0 \%)$ & $5(6.3 \%)$ & $9(7.5 \%)$ & \\
\hline \multicolumn{6}{|c|}{ Preferred Language } \\
\hline & English & $147(73.9 \%)$ & $46(58.3 \%)$ & $101(84.2 \%)$ & $<0.001$ \\
\hline & Spanish & $52(26.1 \%)$ & $33(41.7 \%)$ & $19(15.8 \%)$ & \\
\hline
\end{tabular}


medRxiv preprint doi: https://doi.org/10.1101/2022.02.16.22271085; this version posted February 17, 2022. The copyright holder for this preprint (which was not certified by peer review) is the author/funder, who has granted medRxiv a license to display the preprint in perpetuity. It is made available under a CC-BY-NC-ND 4.0 International license.

Table 2: NLP and ICD9/10 compared with MMSE (inclusive of notes +/- 1 year of MMSE)

\begin{tabular}{|l|c|c|c|}
\hline & NLP & ICD & NLP/ICD \\
\hline Sensitivity & $0.35(0.25-0.47)$ & $0.24(0.13-0.59)$ & $0.41(0.30-0.52)$ \\
\hline Specificity & $0.66(0.57-0.74)$ & $0.79(0.60-0.91)$ & $0.63(0.54-0.72)$ \\
\hline Precision & $0.41(0.29-0.53)$ & $0.43(0.19-0.75)$ & $0.42(0.31-0.54)$ \\
\hline NPV & $0.61(0.52-0.69)$ & $0.61(0.50-0.82)$ & $0.62(0.53-0.70)$ \\
\hline F1 Score & 0.38 & 0.31 & 0.41 \\
\hline
\end{tabular}

470

471 
medRxiv preprint doi: https://doi.org/10.1101/2022.02.16.22271085; this version posted February 17, 2022. The copyright holder for this preprint (which was not certified by peer review) is the author/funder, who has granted medRxiv a license to display the preprint in perpetuity. It is made available under a CC-BY-NC-ND 4.0 International license .

472 Table 3: NLP and ICD9/10 compared with Manual Chart Review (inclusive of all notes) 473

\begin{tabular}{|l|c|c|c|}
\hline & NLP & ICD & NLP/ICD \\
\hline Sensitivity & $0.96(0.75-1.00)$ & $0.77(0.46-0.95)$ & $0.96(0.75-1.00)$ \\
\hline Specificity & $0.68(0.50-0.82)$ & $0.92(0.78-0.98)$ & $0.68(0.50-0.82)$ \\
\hline Precision & $0.52(0.31-0.72)$ & $0.77(0.46-0.95)$ & $0.52(0.31-0.72)$ \\
\hline NPV & $0.98(0.86-1.00)$ & $0.92(0.78-0.98)$ & $0.98(0.86-1.00)$ \\
\hline F1 Score & 0.68 & 0.77 & 0.68 \\
\hline
\end{tabular}

474 
Table 4: Machine Learning Applied to NLP extracted terms compared with MMSE

\begin{tabular}{|l|c|c|c|}
\hline & Logistic Regression & MLP & Random Forest \\
\hline Sensitivity & 0.63 & 0.94 & 0.95 \\
\hline Specificity & 0.98 & 1.00 & 1.00 \\
\hline Precision & 0.95 & 1.00 & 1.00 \\
\hline NPV & 0.79 & 0.96 & 0.97 \\
\hline F1 Score & 0.76 & 0.97 & 0.98 \\
\hline AUC & 0.80 & 0.97 & 0.98 \\
\hline
\end{tabular}

1. Ward A, Arrighi HM, Michels S, et al. Mild cognitive impairment: Disparity of incidence and

2. Langa KM, Larson $\mathrm{EB}, \mathrm{Crimmins} \mathrm{EM}$, et al. A comparison of the prevalence of dementia in the United States in 2000 and 2012. JAMA Internal Medicine 2017.

4. Borson S, Frank L, Bayley PJ, et al.: Improving dementia care: The role of screening and detection

5. Wilkinson T, Ly A, Schnier C, et al. Identifying dementia cases with routinely collected health data: A systematic review. Alzheimers Dement 2018; 14: 1038-1051.

494

495

496

497

6. Scott J, Mayo AM. Instruments for detection and screening of cognitive impairment for older adults in primary care settings: A review. Geriatric Nursing 2018.

7. Kotagal V, Langa KM, Plassman BL, et al. Factors associated with cognitive evaluations in the United States. Neurology 2015.

8. Moga DC, Roberts M, Jicha G: Dementia for the Primary Care Provider. In Primary Care - Clinics in Office Practice, 2017

9. Boustani M. Dementia Screening in Primary Care: Not Too Fast! Journal of the American Geriatrics Society 2013.

10. Linzer M, Poplau S, Babbott S, et al. Worklife and Wellness in Academic General Internal Medicine: Results from a National Survey. Journal of General Internal Medicine 2016.

11. Rabatin J, Williams E, Baier Manwell L, et al:: Predictors and Outcomes of Burnout in Primary Care Physicians. In Journal of Primary Care \& Community Health, 2016 
medRxiv preprint doi: https://doi.org/10.1101/2022.02.16.22271085; this version posted February 17, 2022. The copyright holder for this preprint (which was not certified by peer review) is the author/funder, who has granted medRxiv a license to display the preprint in perpetuity.

It is made available under a CC-BY-NC-ND 4.0 International license .

12. Zhang R, Simon G, Yu F: Advancing Alzheimer's research: A review of big data promises. In International Journal of Medical Informatics, 2017

13. Nadkarni PM, Ohno-Machado L, Chapman WW: Natural language processing: An introduction. In Journal of the American Medical Informatics Association, 2011

14. Levin MA, Joseph TT, Jeff JM, et al. IGAS: A framework for using electronic intraoperative medical records for genomic discovery. Journal of Biomedical Informatics 2017.

15. Krauskopf K, Federman AD, Kale MS, et al. Chronic obstructive pulmonary disease illness and medication beliefs are associated with medication adherence. COPD: Journal of Chronic Obstructive Pulmonary Disease 2015.

16. Ray M, Sano M, Wisnivesky JP, et al. Asthma control and cognitive function in a cohort of elderly adults. Journal of the American Geriatrics Society 2015.

17. Folstein MF, Folstein SE, McHugh PR. "Mini-mental state": A practical method for grading the cognitive state of patients for the clinician. Journal of Psychiatric Research 1975; 12: 189-198.

18. Spackman KA, Campbell KE, Côté RA. SNOMED RT: a reference terminology for health care. Proceedings : a conference of the American Medical Informatics Association AMIA Fall Symposium 1997.

19. St Germaine-Smith C, Metcalfe A, Pringsheim T, et al. Recommendations for optimal ICD codes to study neurologic conditions: a systematic review. Neurology 2012; 79: 1049-1055.

20. Reuben DB, Hackbarth AS, Wenger NS, et al. An Automated Approach to Identifying Patients with Dementia Using Electronic Medical Records. Journal of the American Geriatrics Society 2017; 65: 658-659.

21. Pal SK, Mitra S. Multilayer perceptron, fuzzy sets, and classification. IEEE Transactions on Neural Networks 1992; 3: 683-697.

22. Breiman L. Random Forrests. Machine learning 2001.

23. Mirheidari B, Blackburn D, Harkness $\mathrm{K}$, et al.: An avatar-based system for identifying individuals likely to develop dementia. In Proceedings of the Annual Conference of the International Speech Communication Association, INTERSPEECH, 2017

24. Thomas C, Kešelj V, Cercone N, et al.: Automatic detection and rating of dementia of alzheimer type through lexical analysis of spontaneous speech. In IEEE International Conference on Mechatronics and Automation, ICMA 2005, 2005

25. Orimaye SO, Wong JS-M, Golden KJ, et al. Predicting probable Alzheimer's disease using linguistic deficits and biomarkers. BMC Bioinformatics 2017; 18: 34. 
26. Greenwald JL, Cronin PR, Carballo V, et al. A Novel Model for Predicting Rehospitalization Risk Incorporating Physical Function, Cognitive Status, and Psychosocial Support Using Natural Language Processing. Medical Care 2017.

27. Callahan KE, Lovato JF, Miller ME, et al. Associations between mild cognitive impairment and hospitalization and readmission. Journal of the American Geriatrics Society 2015.

28. Lin PJ, Zhong Y, Fillit HM, et al. Medicare Expenditures of Individuals with Alzheimer's Disease and Related Dementias or Mild Cognitive Impairment Before and After Diagnosis. Journal of the American Geriatrics Society 2016.

29. Lin PJ, Neumann PJ: The economics of mild cognitive impairment. In Alzheimer's and Dementia, 2013

30. Soones TN, Lin JL, Wolf MS, et al. Pathways linking health literacy, health beliefs, and cognition to medication adherence in older adults with asthma. Journal of Allergy and Clinical Immunology 2017.

31. Dotson VM, Resnick SM, Zonderman AB. Differential association of concurrent, baseline, and average depressive symptoms with cognitive decline in older adults. American Journal of Geriatric Psychiatry 2008.

32. Stuck AE, Walthert JM, Nikolaus T, et al.: Risk factors for functional status decline in communityliving elderly people: A systematic literature review. In Social Science and Medicine, 1999

33. Sanders JB, Bremmer MA, Comijs HC, et al. Cognitive functioning and the natural course of depressive symptoms in late life. American Journal of Geriatric Psychiatry 2011.

34. 2019 ALZHEIMER'S DISEASE FACTS AND FIGURES Includes a Special Report on Alzheimer's Detection in the Primary Care Setting: Connecting Patients and Physicians. In

35. National Plan to Address Alzheimer's Disease: 2018 Update. . In

36. Hong Y, Jang E, Hwang J, et al. The Efficacy of Cognitive Intervention Programs for Mild Cognitive Impairment: A Systematic Review. Current Alzheimer Research 2015.

37. Backhouse A, Ukoumunne OC, Richards DA, et al. The effectiveness of community-based coordinating interventions in dementia care: A meta-analysis and subgroup analysis of intervention components. BMC Health Services Research 2017.

38. Crum RM. Population-Based Norms for the Mini-Mental State Examination by Age and Educational Level. JAMA: The Journal of the American Medical Association 1993; 269: 2386.

39. Creavin ST, Wisniewski S, Noel-Storr AH, et al. Mini-Mental State Examination (MMSE) for the detection of dementia in clinically unevaluated people aged 65 and over in community and primary care populations. Cochrane Database of Systematic Reviews 2016. 
medRxiv preprint doi: https://doi.org/10.1101/2022.02.16.22271085; this version posted February 17, 2022. The copyright holder for this preprint (which was not certified by peer review) is the author/funder, who has granted medRxiv a license to display the preprint in perpetuity. It is made available under a CC-BY-NC-ND 4.0 International license.

606

607

608

609

610

611

612

613

614

615
40. Berkman LF. The association between educational attainment and mental status examinations: Of etiologic significance for senile dementias or not? Journal of Chronic Diseases 1986.

41. Roberts R, Knopman DS: Classification and epidemiology of $\mathrm{MCl}$. In Clinics in Geriatric Medicine, 2013

42. Bradford A, Kunik ME, Schulz P, et al.: Missed and delayed diagnosis of dementia in primary care: Prevalence and contributing factors. In Alzheimer Disease and Associated Disorders, 2009 